\title{
ОКРЕМІ ПИТАННЯ ПОБУДОВИ ВІЙСЬКОВОГО СУДОЧИНСТВА В УКРАЇНІ НА ОСНОВІ МІЖНАРОДНОГО ДОСВІДУ
}

\author{
ЧЕРНОВСЬКИЙ Олексій Костянтинович - доктор юридичних наук, суддя \\ у відставці, заслужений юрист України \\ ІЛ'ЮК Дмитро Дмитрович - магістр права, лейтенант юстиції, старший \\ офіцер відділу організації правової роботи Управління правового забезпечення \\ Генерального штабу Збройних Сил України
}

DOI:10.32782/NP.2020.1.28

B статье рассмотрень построение системъ военного судопроизводства в странах Европейского Союза и ее перспективъ развития с учетом результатов рассмотрения дела «Финдли против соединенного Королевства", которое слушалось в Европейском суде по правам человека в 1997 году и начала процесса изивлианизации системъ военного судопроизводства.

Прочесс ицвилианизачии бълл въъзан тем, ито Европейский суд по правам человека по делу «Финдли против Соединенного Королевства» пришел к въгводу, что для того, итобы сиитать суд "независимьлм", нужно обратить внимание на способ назначения его членов и сроки их полномочий, существование гарантий против внешнего давления и наличие внешних признаков независимости.

Коллективом авторов предложено возможную модель построения системъ военного судопроизводства в Украине, учитьвая въводъ Европейского суда по правам человека, с сохранением судебного контроля за секторами безопасности и оборонъ, как одним из элементов демократического гражданского контроля, и привлечением к рассмотрению дел в военной сбере присяжных из числа действующих военнослужащих или военнообязанных запаса, резервистов.

Ключевъе слова: военнъие судъ, военнъий суд, военнъе судъ в Украине, военная судебная система, прислжнъе, военнъие присяжнье, циивилианизация, военная юстиция, военнъие преступления.

\section{Постановка проблеми}

Із початком збройної агресії Російської Федерації проти України, що розпочалась 20 ^ютого 2014 року, порушуючи норми та принципи міжнародного права, двосторонні та багатосторонні угоди, Російською Федерацією було анексовано Автономну республіку Крим і місто Севастополь, окуповано окремі райони Донецької та Ауганської областей. Станом на 2019 рік Збройними Силами України та іншими військовими формуваннями реалізуються заходи із забезпечення національної безпеки і оборони, відсічі і стримування збройної агресії Російської Федерації у Донецькій та Ауганській областях, що потребує залучення великої кількості особового складу до виконання поставлених завдань в умовах особливого періоду.

Ситуація, що склалась, зумовила різке зростання кількості військових злочинів та інших правопорушень, що вчиняються військовослужбовцями та вимагає активної розбудови системи військової юстиції в Україні, зокрема створення військових судів з метою забезпечення професійного і об'єктивного правосуддя для військовослужбовців.

Ступінь наукової розробки проблеми

Дослідженню проблем діяльності військових судів та їх створення, зокрема в Україні, присвячені праці Ю. Боброва, Г. Кваші, Р. Куйбіди, М. Михеєнка, В. Молодована, С. Оверчука, А. Петроченко- 
ва, Г. Рубіна, Я. Романовського, М. Сенька, О. Ткачука, О. Тюріної, $\lambda$. Фесенко, В. Шишкіна та інших.

Метою статті є аналіз систем військового судочинства країн Свропейського Союзу, етапів їх розвитку та трансформування 3 огляду на практику Європейського суду з прав людини у справі “Фіндлі проти Сполученого Королівства" для формування можливої моделі побудови військового судочинства в Україні, яка 6 відповідала вимогам часу та європейським стандартам.

\section{Виклад основного матеріалу}

Із початком збройної агресії Російської Федерації проти України, що розпочалась 20 ^ютого 2014 року, порушуючи норми та принципи міжнародного права, двосторонні та багатосторонні угоди, Російською Федерацією було анексовано Автономну республіку Крим і місто Севастополь, окуповано окремі райони Донецької та Ауганської областей. Станом на 2019 рік Збройними Силами України та іншими військовими формуваннями реалізуються заходи із забезпечення національної безпеки і оборони, відсічі і стримування збройної агресії Російської Федерації у Донецькій та $\lambda$ ганській областях, що потребує залучення великої кількості особового складу до виконання поставлених завдань в умовах особливого періоду.

Ситуація, що склалась, зумовила різке зростання кількості військових злочинів та інших правопорушень, що вчиняються військовослужбовцями та вимагає активної розбудови системи військової юстиції в Україні, зокрема створення військових судів з метою забезпечення професійного і об'єктивного правосуддя для військовослужбовців.

На сьогодні військові суди діють майже в 40 розвинених країнах світу, у тому числі і Європи, які мають власні збройні сили. Провівши аналіз діяльності військових судів у країнах Європи можна констатувати, що в кількісному стосунку серед країн Європейського Союзу існує абсолютний пріоритет в усвідомленні необхідності існування військових судів; легітимізація їхньої діяль- ності підтверджена як Свропейським судом з прав людини, так і Постійним комітетом Ради Європи. Інша річ, що наявні військові суди в державах-членах Свропейського Союзу функціонують на різних принципових засадах, мають різні характеристики за складом, повноваженнями тощо. Отже, ïx можна класифікувати на підставі певних критеріїв, виокремити базисні модельні риси, спрогнозувати можливість адаптації тих чи інших моделей (або їх елементів) в Україні з урахуванням як мирного часу, так і в умовах особливого періоду, стану війни або воєнного стану [1, с. 11].

У додатку до звіту 55-ї зустрічі Керівного комітету з прав людини Ради Европи виокремлюються три типи держав, у яких діють військові суди, про що згадує О. Ткачук у своїх дослідженнях про механізми реалізації правосуддя в збройних силах [6].

Перший тип - держави, де військові суди функціонують на постійній основі (як самостійні органи судової влади в мирний і воєнний час для розгляду кримінальних, адміністративних і дисциплінарних справ військовослужбовців). Це такі країни, як Великобританія, Іспанія, Італія, Ірландія, Словаччина та деякі інші.

Другий тип - держави із змішаною юрисдикцією військових судів (Функціонують при загальних цивільних судах; існують спеціалізовані військові структури (палати, відділи тощо), а склад таких структур, як правило, формується з військових і цивільних суддів). До таких держав належать Франція, Нідерланди, Фінляндія, Угорщина, Болгарія, Бельгія, Хорватія та інші.

Третій тип - держави, у яких військові суди діють лише у воєнний час і за кордоном на території військових баз (у мирний час справи військовослужбовців розглядаються цивільними судами, але в деяких країнах до складу суду можуть уводитись i військові судді; в окремих країнах діє військово-кримінальне законодавство). Такими країнами є Австрія, Німеччина, Португалія, Данія, Чехія та інші [8].

Практика судочинства в різних країнах не створила єдиної універсальної моделі військового правосуддя. Кожна країна при цьому враховувала свій власний історич- 


\section{Військове судочинство}

ний досвід, економічні можливості, правову практику, стан збройних сил та низку інших факторів [6].

Військові суди в Україні було ліквідовано у 2010 році. До ліквідації вони належали до загальних судів і здійснювали правосуддя у Збройних Силах України та інших військових формуваннях, утворених відповідно до закону. Військовими судами вважались: військові суди гарнізонів, військові суди регіонів та Апеляційний суд Військово-Морських сил. Окрім того, у складі касаційного та Верховного судів діяли, відповідно, Військова судова палата та Військова судова колегія. На момент ліквідації військових судів до їх компетенції був віднесений розгляд виключно кримінальних справ та справ про корупційні адміністративні правопорушення. Причому військовим судам гарнізонів як судам першої інстанції були підсудні справи про злочини осіб, які мають військове звання до підполковника, капітана 2 рангу включно, крім тих справ, які були підсудні військовим судам вищого рівня. Військовим судам регіонів, Військово-Морських сил як судам першої інстанції були підсудні справи про злочини осіб, які мають військове звання полковника, капітана 1 рангу і вище, справи про злочини осіб, які займають посаду від командира полку, командира корабля 1 рангу і вище, та осіб, рівних їм за службовим становищем, а також справи про всі злочини, за які в умовах мирного часу законом передбачена можливість призначення покарання у вигляді довічного позбавлення волі.

Окрім перелічених вище категорій справ, раніше військовим судам також були підвідомчі й справи про всі злочини, скоєні військовослужбовцями ЗСУ, прикордонних військ, Служби Безпеки України та інших військових формувань, а також військовозобов'язаними під час проходження ними зборів, та всі справи про шпигунство. А також деякі інші категорії справ, у тому числі справи, пов'язані із захистом прав і свобод військовослужбовців. Що стосується правового статусу судді військового суду, то на момент ліквідації цих судів відмінність його від правового статусу інших служителів Феміди полягала в тому, що перший перебував на військовій службі у ЗСУ та мав офіцерське звання. Додатковою гарантією незалежності судді військового суду була законодавча заборона залучати його до виконання інших обов'язків військової служби, крім здійснення правосуддя. На суддю цього суду поширювалися гарантії незалежності, аналогічні тим, які мали на той момент інші володарі мантій. Порядок їх призначення на посади також нічим не відрізнявся.

Евген Сидоров, суддя Шевченківського районного суду м. Києва, колишній заступник голови Військового місцевого суду Хмельницького гарнізону вважає, що на час ліквідації військові суди за всіма міжнародними стандартами можна було вважати належними для розгляду тієї категорії справ, які були віднесені до їх компетенції [9].

у той же час, у висновках експерта Ради Европи, заступника голови суду міста Утрехт (Нідерланди) пані Рози Г.М. Янсен щодо “Концепції удосконалення судового устрою та забезпечення справедливого судочинства в Україні відповідно до європейських стандартів" від 13 лютого 2006 року зазначено, що включення військових судів до судової системи створює подвійну проблему. По-перше, військові судді таких судів дуже часто мають значно меншу незалежність. По-друге, функціонування військових судів обмежує юрисдикцію цивільних судів, які захищені гарантіями незалежності, або може бути альтернативним судочинством 3 нечітко визначеними повноваженнями. 3 огляду на це, важливо скасувати військові суди в загальній судовій системі [10].

Таким чином, Концепція вдосконалення судівництва, схвалена Указом Президента України від 10 травня 2006 року№ 361/2006, закріпила, що у судовій системі України не повинно бути такого виду судів, як військові суди.

Р. Куйбіда відзначав, що ліквідація військових судів не відкидатиме можливості запровадження в судах загальної юрисдикції спеціалізації суддів із розгляду справ у галузі військових правовідносин, однак 
правовий статус таких суддів не повинен мати ніяких особливостей.

Схожу позицію висловлював і В. Шишкін, який пропонував скасувати військові суди, а справи передати на розгляд до звичайних судів, утворивши в них спеціалізацію суддів для розгляду справ про військові злочини. На думку С. Оверчука, такий спосіб внутрішньої спеціалізації окремих судів є доцільним тільки у разі створення відповідних судових палат [3].

Однією 3 передумов скасування військових судів, на думку Я. Романовського, могло бути те, що судді військових судів мали особливий статус, зокрема перебували на військовій службі, мали військові звання, отримували доплати за військові звання. Це суперечило принципу єдності статусу суддів і не відповідало європейським стандартам, як їх тлумачить Європейський суд 3 прав людини.

Показовою справою в частині розбудови військового судочинства є справа “Фіндлі проти Сполученого Королівства”, яка слухалась у Европейському суді з прав людини у 1997 році. За результатами розгляду цієї справи був прийнятий Armed Forces Act у 2006 році [11] та була перебудована система військового судочинства у Сполученому Королівстві. Так, у 2004 році суд Королівських сухопутних військ та суд Королівських повітряних сил було об'єднано та утворено Службу військових судів (Military Court Service), а у 2007 році до неї було приєднано суд Королівських військовоморських сил. Служба військових судів є незалежною від військового командування організацією, яка комплектується з цивільних службовців, деякі з яких мають досвід військової служби [12].

Г. Рубін з Кентського університету в Кантербері (Об'єднане королівство) зазначає, що цим завершився процес цивіліанізації (civilianisation) військового судочинства [13].

Процес цивіліанізації був спричинений тим, що Европейський суд з прав людини у справі “Фіндлі проти Сполученого Королівства" дійшов висновку, що для того, щоб вважати суд “незалежним” потрібно звернути увагу на спосіб призначення його членів та строки їх повноважень, існування гарантій проти зовнішнього тиску та наявність зовнішніх ознак незалежності [14].

На нашу думку, слід розглядати проблему створення та діяльності військового судочинства через призму історичного досвіду України, ії економічних можливостей, особливостей законодавства України, що регулює правовідносини у військовій сфері та міжнародний досвід у зазначеній сфері. Так, Законом України "Про національну безпеку України” від 21 червня 2018 року № 2469-VIII визначаються та розмежовуються повноваження державних органів у сферах національної безпеки і оборони та, крім іншого, забезпечується демократичний цивільний контроль над органами та формуваннями сектору безпеки і оборони. Зокрема, одним із елементів системи демократичного цивільного контролю визначено судовий контроль [2].

Військові, науковці, практикуючі судді (які є як прихильниками, так і опонентами створення військових судів, як окремої вертикалі в загальній системі) все ж сходяться в думці, що для повного, всебічного та об'єктивного вирішення справ про вчинення військових злочинів, деяких військових адміністративних чи дисциплінарних правопорушень необхідні специфічні знання у військовій сфері. Отже, вважаємо, що доцільно було б розглядати створення системи військового судочинства в Україні із збереженням демократичного цивільного контролю над сектором безпеки і оборони.

Враховуючи зазначене вище, пропонуємо доповнити чинне законодавство положеннями, які дозволяли б судді під час розгляду справи у військовій сфері залучати до розгляду справи присяжних за клопотанням однієї із сторін по справі або на власний розсуд з числа:

1) військовослужбовців 3 числа осіб офіцерського та старшого сержантського (старшинського) складу, мають військові звання не нижчі, ніж одна із сторін по справі та досвід військової служби не менше5 років у календарному обчисленні;

2) осіб, які перебувають на військовому обліку в запасі з числа осіб офіцерського та старшого сержантського (старшин- 


\section{Військове судочинство}

ського) складу, мають військові звання не нижчі, ніж одна із сторін по справі та досвід військової служби не менше 5 років у календарному обчисленні.

Суд (журі) присяжних - різновид розгляду справи в суді, при якому рішення по суті справи приймають непрофесійні судді. Розрізняють класичну (англо-американську) модель журі присяжних, яка в декілька адаптованому вигляді впроваджена в ряді держав, що належать до романо-германської правової сім’ї (Грузія, Іспанія, Росія та ін.), і континентальну модель, сприйняту багатьма європейськими державами, в т.ч. Україною [15].

Законодавство України модифікувало континентальний варіант суду присяжних. Законодавча база грунтується на частині четвертій статті 124 Конституції України, в якій ідеться, що народ безпосередньо бере участь у здійсненні правосуддя через присяжних. Деталізація згаданої статті знайшла своє відображення у главі 30 розділу IV Кримінально-процесуального кодексу України та главу 3 розділу III Закону України "Про судоустрій і статус суддів".

Відповідно до чинного законодавства можна виділити такі характерні риси суду присяжних в Україні:

реалізується тільки при місцевому загальному суді першої інстанції і лише за звинуваченнями, за які передбачено довічне позбавлення волі;

професійні судді й присяжні разом вирішують питання предмета конфлікту включно 3 юридичними нюансами та ухвалюють спільне рішення. Англо-американська модель передбачає, що представники народу вирішують тільки питання суті, тобто винна особа чи ні, а професійний суддя визначає вид і міру покарання;

в класичній системі рішення суду присяжних зазвичай не оскаржується. В Україні ж можна подати скаргу в апеляційну інстанцію і вже професійні судді мають право скасувати будь-яке рішення присяжних, а не тільки міру покарання за вчинене правопорушення [16].

Така система повністю нівелює цей інститут народовладдя в частині здійснення правосуддя.
С. Овчерук вважає, що військові суди $\epsilon$ необхідною складовою як військової, так і кримінальної юстиції в Україні. Впровадження військового правосуддя має відбуватися не у формі механічного відновлення радянської системи військових трибуналів, а шляхом створення військових судів на якісно нових засадах. Питання їх діяльності нерозривно пов'язане 3 цілим комплексом проблем судоустрою, судочинства, державної влади, вирішення яких повинне мати комплексний характер. Науковець стверджує, що в Україні є доцільним створення системи спеціалізованих військових судів, які $б$ відповідали міжнародним стандартам 3 точки зору як організації, так і механізму здійснення правосуддя у Збройних Силах України [3, c.38-39].

Беззаперечно, існують справи у військовій сфері, які потребують не лише кваліфікованого судового розгляду професійними суддями (компетентними юристами), а й спеціальних знань у військовій сфері, розуміння ії специфіки і володіння великим масивом нормативно-правової бази, яка регулює порядок та умови проходження військової служби.

14 січня 2016 року Президент України підписав Закон України "Про Державне бюро розслідувань”, а постановою Кабінету Міністрів України від 29 лютого 2016 року № 127 було утворено Державне бюро розслідувань. До підслідності Державного бюро розслідувань, крім іншого, було віднесено розслідування справ про вчинення військових злочинів. Також було утворено мережу територіальних управлінь Державного бюро розслідувань із розташуванням у містах Києві, Краматорську, Аьвові, Мелітополі, Миколаєві, Полтаві та Хмельницьку. За кожним із територіальних управлінь було закріплено ряд областей, на які поширюється їхня юрисдикція.

Починаючи з 27 листопада 2018 року, Державне бюро розслідувань почало здійснювати правоохоронну діяльність з метою запобігання, виявлення, припинення, розкриття та розслідування злочинів, віднесених до його компетенції. 
У зв'язку з цим, вважаємо за доцільне створення окружних військових судів в Україні, як судів першої інстанції з розгляду справ у військовій сфері з територіальною підсудністю справ відповідно до територіальної побудови Державного бюро розслідувань.

Враховуючи наведене вище, в частині визначення підсудності справ окружним військовим судам, як судам першої інстанції, пропонується віднести до їх компетенції розгляд справ, які пов'язані із (вчинені під час) виконання службових обов'язків або обов'язків військової служби, в яких однією із сторін є військовослужбовець або резервіст, який вчинив правопорушення під час проходження навчальних (перевірочних) і спеціальних зборів або військова частина (установа, заклад, організація), крім тих, які віднесені до компетенції Апеляційного військового суду у місті Києві, як суду першої інстанції.

Важко не погодитись із тим, що є ряд незначних за складністю справ про вчинення військових адміністративних правопорушень, які потребують швидкого доступу до правосуддя, тобто розгляду справи за місцем вчинення правопорушення у найкоротші строки. Розгляд такої категорії справ може бути забезпечений місцевими судами загальної юрисдикції.

До компетенції окружних військових судів необхідно віднести справи, в яких однією із сторін $є$ військовослужбовці або резервісти, які вчинили правопорушення під час проходження зборів, або військові частини (установи, заклади, організації), а саме:

про вчинення кримінальних правопорушень під час виконання службових обов'язків;

про вчинення кримінальних правопорушень під час виконання обов'язків військової служби;

справ про вчинення корупційних правопорушень, за які передбачено кримінальну відповідальність;

злочинів проти встановленого порядку несення військової служби, вчинених особами начальницького складу виправнотрудових установ; справи про захист честі та гідності військовослужбовця.

Апеляційну інстанцію пропонується утворити у вигляді єдиного Апеляційного військового суду у місті Києві, юрисдикція якого поширюватиметься на всю територію України. Для призначення на посаду судді окружного військового суду та Апеляційного військового суду у місті Києві особа повинна відповідати вимогам, які висуваються до судді, відповідно до Закону України “Про судоустрій та статус суддів", та мати досвід військової служби на посадах офіцерського складу не менше ніж 10 років у календарному обчисленні.

До компетенції Апеляційного військового суду у місті Києві пропонується віднести наступні категорії справ:

справи, які розглядались місцевими судами загальної юрисдикції, в яких однією із сторін є військовослужбовець або резервіст, який вчинив правопорушення під час виконання службових обов'язків або обов'язків військової служби, проходження навчальних (перевірочних) або спеціальних зборів або військова частина (установа, заклад, організація);

перегляд в апеляційному порядку справ, що розглядались окружними військовими судами;

справи про шпигунство;

розгляд кримінальних справ, як судом першої інстанції, в яких обвинуваченими e військовослужбовці, які мають військове звання полковника, капітана 1 рангу i вище, справи про злочини осіб, які мають займають посаду від командира бригади, корабля 1 рангу і вище, та осіб, рівних їм за службовим становищем, а також справи про всі злочини, за які в умовах мирного часу законом передбачена можливість призначення покарання у вигляді довічного позбавлення волі.

У разі розгляду Апеляційним судом міста Києва справи, як судом першої інстанції, необхідно передбачити можливість для суду залучати до розгляду справи присяжних. Для перегляду справ у касаційному порядку вважаємо за доцільне утворити у складі Верховного суду колегію для розгляду справ у військовій сфері. 


\section{Військове судочинство}

У разі розгляду справи судом присяжних, пропонується наділити присяжних правом вирішення питання тільки по суті, тобто винна особа чи ні, як у класичній системі англо-американської моделі, а професійний суддя (склад суду) визначає вид і міру покарання. Оскарження вироку суду, в такому разі, може відбуватись лише в частині суворості покарання в суді апеляційної чи касаційної інстанції.

Щодо вимог, які висуваються до присяжних для розгляду таких категорій справ, варто зазначити, що це можуть бути військовослужбовці або військовозобов'язані громадяни запасу, які проходять службу у військових частинах чи постійно проживають (у випадку із військовозобов'язаними запасу) на території, яка входить у межі гарнізону, на якій знаходиться суд (або поширюється юрисдикція суду), в якому розглядається справа та мають військові звання старшого сержантського (старшинського) або офіцерського складу, але не нижчі, ніж військове звання особи, яка є стороною у справі.

Не може бути присяжним у справі військовослужбовець однієї й тої самої військової частини, що й військовослужбовець, який $є$ обвинуваченим по справі або військовозобов'язаний запасу, який колись проходив службу у тій же військовій частині, що й військовослужбовець, який є обвинуваченим по справі.

\section{Література}

1. Військові суди: скасувати не можна залишити? [Електронний ресурс]. - Режим доступу: https://yurincom.com/ru/yuridichnyi_visnyk_ukrainy/overview/?id $=676$.

2. Закон України «Про національну безпеку і оборону» [Електронний ресурс]. - Peжим доступу: https://zakon.rada.gov.ua/laws/ show/2469-19.

3. Кухта М.М. Військові суди в Україні - сучасна потреба суспільства / М. М. Кухта // Право та державне управління. - 2016. -№ 4. - С. 36-41. - Режим доступу: http://nbuv. gov.ua/UJRN/Ptdu_2016_4_8.

4. Проект Закону про внесення змін до Закону України «Про судоустрій i статус суддів» щодо військових судів-
№ 8392-1 [Електронний ресурс]. - Режим доступу: http://w1.c1.rada.gov.ua/pls/zweb2/ webproc4_1?pf3511=64138.

5. Проект Закону про внесення змін до Закону України «Про судоустрій i статус суддів» щодо військових судів№ 8392 [Електронний ресурс]. - Режим доступу: http://w1.c1.rada.gov.ua/pls/zweb2/ webproc4_1?pf3511 $=64070$.

6. Оверчук С.В. Військові суди - необхідна складова військової юстиції в Україні / Оверчук C.B. // Часопис Національного університету «Острозька академія»: [Електронний ресурс] - Режим доступу: https:// lj.oa.edu.ua/articles/2015/n1/15osvyvu.pdf.

7. Середюк В. Юрисдикція судів України за спеціалізацією : автореферат дис. ... канд. юрид. наук: 12.00 .10 / В. Середюк Київ, 2003. - 22 с.

8. Ткачук О. Військові суди України як складова частина судів загальної юрисдикції / О. Ткачук // Право України. - 2006 . № 4. - С. 117-119.

9. Сидоров С. Щодо необхідності повернення військових судів [Електронний ресурс]. - Режим доступу: https://radako.com. ua/news/shchodo-neobhidnosti-povernennyaviyskovih-sudiv.

10. Янсен Р. Концепції удосконалення судового устрою та забезпечення справедливого судочинства в Україні відповідно до європейських стандартів [Електронний ресурс]. - Режим доступу: https://minjust.gov. $\mathrm{ua} / \mathrm{m} / \mathrm{str} 7624$.

11. Armed Forces Act 2006 Chapter 52 [Електронний ресурс]. - Режим доступу: http://www.legislation.gov.uk/ukpga/2006/52/ pdfs/ukpga_20060052_en.pdf.

12. Guidance "The Military Court Service" [Електронний ресурс]. - Режим доступу: https://www.gov.uk/guidance/the-militarycourt-service\# related-information.

13. Рубін $Г$. United Kingdom Military Law: Autonomy, Civilianisation, Juridification [Електронний ресурс]. - Режим доступу: https://military-justice.ca/wp-content/uploads/2018/11/United-Kingdom-Military-LawAutonomy-Civilization-Juridification.pdf.

14. Европейський суд з прав людини "Фіндлі проти Сполученого Королівства" [Електронний ресурс]. - Режим доступу: 


\begin{tabular}{|c|}
\hline 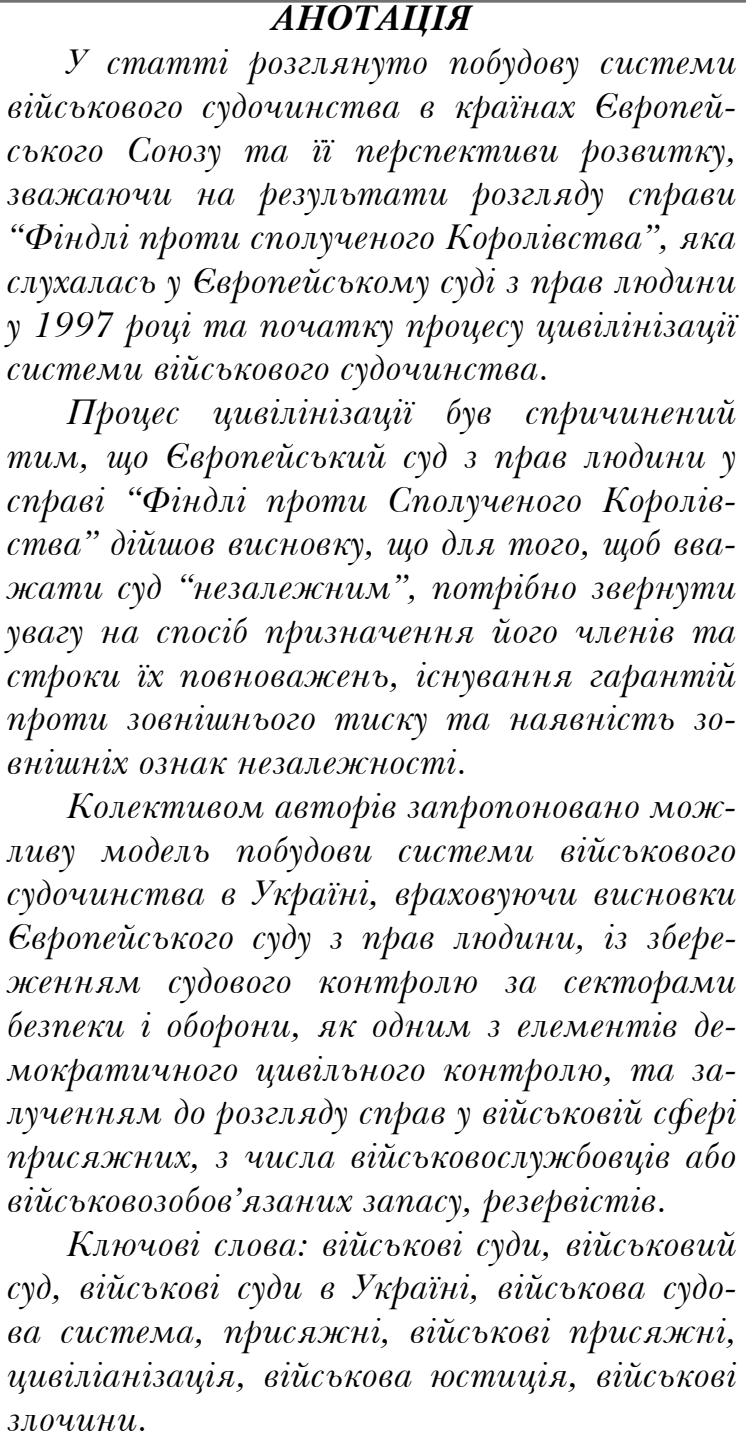 \\
\hline
\end{tabular}

https://hudoc.echr.coe.int/eng\#\{\%22item id\%22:[\%22001-58016\%22]\}.

15. Суд присяжних: загальна характеристика та особливості імплементації

SUMMARY
The article reviews the construction of military
justice system in countries of the European Union
and its development aspects, taking into account the
findings of the Findlay v. United Kingdom case,
heard at the European Court of Human Rights
in 1997 and the start of the military justice system
civilization process.
The process of civilization was caused by the
fact that in the case of Findley v. The United
Kingdom the European Court of Human Rights
came to a conclusion that to consider the court
independent we should to pay attention to the
method of appointing its members and the term of
their authority, the existence of safeguards against
external pressure and the existence of external signs
of independence.
Authors proposing a possible model of building
a military justice system in Ukraine, taking into
account the findings of the European Court of
Human Rights. Also, saving judicial control over
the security and defense sectors as one of element
of democratic civilian control, and involving the
jury in cases in military sphere from among of the
current or former service members, reservists.
Key words: courts martial, court martial,
courts martial in Ukraine, military court system,
jurors, military jurors, lay members, civilizing,
civilianization, military justice, war crimes.

в Україні // Судебно-юридическая газета: [Електронний ресурс] - Режим доступу: https://sud.ua/ru/blog/blog/88513syd-prisyazhnih-zagalna-harakteristika-taosoblivost-mplementats-v-ykran.

16. Чебарай Г. Присяжні. Судді без мантій // Журнал “Тиждень”: [Електронний ресурс] - Режим доступу: https://tyzhden.ua/. 